\title{
Colleges of Education Graduates Academic Achievements in Visual Arts and Quality Delivering of Primary Schools Creative Arts Curriculum in Ghana
}

\author{
Johnson Kofi Kassah", ", Agbeyewornu Kofi Kemevor ${ }^{2}$, Godwin Gbadagba ${ }^{3, *}$ \\ ${ }^{1}$ Department of Vocational Education, St. Francis College of Education, Hohoe, Ghana \\ ${ }^{2}$ Department of Graphic Design, University of Education-Winneba, Winneba, Ghana \\ ${ }^{3}$ Department of Vocational Education, Dambai College of Education, Dambai, Ghana \\ Email address: \\ johnson.kassah@yahoo.com (J. K. Kassah) \\ ${ }^{*}$ Corresponding author
}

\section{To cite this article:}

Johnson Kofi Kassah, Agbeyewornu Kofi Kemevor, Godwin Gbadagba. Colleges of Education Graduates Academic Achievements in Visual Arts and Quality Delivering of Primary Schools Creative Arts Curriculum in Ghana. International Journal of Elementary Education. Vol. 8, No. 3, 2019, pp. 58-62. doi: 10.11648/j.ijeedu.20190803.11

Received: July 16, 2019; Accepted: August 12, 2019; Published: August 23, 2019

\begin{abstract}
The aim of this study was to investigate the colleges of education graduates academic achievements in visual arts and their subject matter competency for quality delivering of primary schools creative arts curriculum in Ghana. The study employed cross-sectional survey design. The study targeted visual arts lecturers and graduates of colleges of education. The sample size for the study was 241 ( 5 lecturers \& 236 graduates). The instruments used for data collection were questionnaire and interview guide. The findings of $\mathrm{H}_{1}$ indicated that colleges of education graduates academic achievements in visual arts have no relationship with their subject matter competency for quality delivering of primary schools creative arts curriculum. The results of $\mathrm{HO}_{2}$ revealed that teaching and learning resources have positive relationship with the quality delivering of primary schools creative arts curriculum. The study revealed that colleges of education graduates academic achievements in visual arts do not reflect their subject matter competency for quality delivering of the primary school creative arts curriculum. The study also found out that teaching and learning resources were not available for quality delivering of primary schools creative arts curriculum. The study recommended that Ghana Education Service should liaise with visual arts units in colleges of education to periodically organise workshops and seminars for primary school teachers to enhance their subject matter competency. The study also recommended that government should supply creative arts textbooks, modern visual arts teaching and learning resources and tools and materials lacking in primary schools to promote effective teaching and learning of creative arts.
\end{abstract}

Keywords: Visual Arts, Colleges of Education, Academic Achievements

\section{Introduction}

Teaching and learning of visual arts in colleges of education in Ghana is to enable trainee teachers acquire basic skills in visual arts to teach at basic level of education, transmit and preserve Ghanaian culture, provide jobs for learners and finally to generate income for learners and the government [1]. Academic achievements refer to learners' success in learning specified curriculum content as discovered by continuous evaluation and examination [2]. Academic achievement is a degree of students' success in performing particular tasks in a subject or area of study after a teaching and learning experience [3]. Academic achievement is designated by grades, tests and examinations scores which show learners' educational reputations [4]. Academic achievement denotes how learners deal with their studies and how they successfully cope with diverse tasks assign to them by their teachers in a specific time or academic year [5]. Academic achievement consists of students' performance in tests, course work and examinations in each year which culminates in a Grade Point Average [6]. Academic achievement is the degree to which educational 
stakeholders achieved their educational objectives measured by examination or continuous assessment evaluation through the grading system which ranges from grades A to E [7]. The main purpose of this study was to find out if colleges of education graduates academic achievements in visual arts reflect their subject matter competencies for quality delivering of primary schools creative arts curriculum. This study also aims to contribute to the existing knowledge by documenting the teaching and learning resources available for quality delivering of creative arts curriculum in primary schools in Ghana.

\subsection{Statement of the Problem}

Teaching and learning of visual arts in colleges of education in Ghana is to enable trainee teachers acquire basic skills in visual arts to teach at basic level of education. There have been complains that trained teachers from colleges of education academic achievements in visual arts during their training in college do not reflect the skills they possess to deliver the contents of the creative arts curriculum in basic schools effectively. This study was to find out if colleges of education graduates academic achievements in visual arts reflect their subject matter competency for quality delivering of primary schools creative arts curriculum in Ghana. The study also intended to assess the teaching and learning resources available for quality delivering of art creative arts curriculum.

\subsection{Objectives}

i. To find out if colleges of education graduates academic achievements in visual arts reflect their subject matter competency for quality delivering of primary schools creative arts curriculum in Ghana.

ii. To assess the teaching and learning resources available for quality delivering of primary schools creative arts curriculum in Ghana.

\subsection{Hypotheses}

$\mathrm{HO}_{1}$ : Colleges of education graduates academic achievements in visual arts have no relationship with their subject matter competency for quality delivering of primary school creative arts curriculum.

$\mathrm{HO}_{2}$ : Visual arts teaching and learning resources have no relationship with the quality delivering of primary schools creative arts curriculum.

\section{Research Design}

This study employed cross-sectional survey design to obtain both qualitative and quantitative data. The cross-sectional survey was used because it allows for large amount of data to be collected within a short time. It also permits researchers to use varieties of research instruments such as questionnaire (closed-ended \& open-ended), interview guide, observation and documents analysis to obtain in-depth knowledge of the problem under investigation. Cross-sectional survey is a research design used for investigating studies that cross diverse sections by amalgamating qualitative and quantitative methods to make inferences about a population of interest at one point in time [8]. The cross-sectional survey design is a research approach in which instead of a researcher using a census or a comprehensive list to obtain data in the target population, the researcher collects data on merely a trivial part of the population to get information about the sampled elements of the whole population.

\subsection{Target Population}

A target population is an entire group of individuals with a specialised set of characteristics [9]. This study targeted colleges of education graduates teaching in primary schools in Volta and Oti regions of Ghana who studied visual arts as a compulsory and an elective subject. The study also targeted visual arts lecturers of colleges of education in Volta and Oti regions of Ghana namely; St. Francis College of Education, Peki College of Education and Dambai College of Education.

\subsection{Sampling Techniques}

The sampling techniques employed in this research were purposive and snowball sampling techniques. There are different categories of teachers teaching in Ghana basic schools. These include pupil teachers who completed senior high school or technical and vocational institutions, nonprofessional teachers who completed polytechnics and universities and trained teachers from colleges of education and teacher training universities. Purposive sampling was used to select only trained teachers from colleges of education who studied visual arts as a compulsory and an elective subject. Purposive sampling is a deliberate selection of respondents due to the abilities and experience they have about the problem under investigation [10]. Purposive sampling comprises identification and selection of participants that are expert and well-informed with a phenomenon of interest [11].

The snowball sampling technique was used to trace 236 colleges of education graduates who studied visual arts as a compulsory and an elective subject and are teaching in primary schools in Volta and Oti regions of Ghana. Snowball sampling technique is useful when samples with the target characteristics are not easily accessible [12]. Snowball or chain sampling is a technique used for discovering research elements in which one element gives the researcher the name of another element, who in turn furnish the name of a third, and so on [13].

\subsection{Sample Size}

A sample size is the number of elements that were selected from which information were collected. A sample size is not the proportion of the research population that gets sampled, but the total size of individual samples selected or observations used in a survey or experiment [14]. In this study, the sample size was 241 (236 trained teachers from colleges of education teaching in primary schools \& 5 colleges of education visual arts tutors) in Volta and Oti regions of Ghana. Table 1 indicates 
the breakdown of the sample size.

Table 1. Sample Size of the Study.

\begin{tabular}{ll}
\hline Respondents & Population \\
\hline Primary School Teachers who Studied Visual Arts & 236 \\
Art tutors of Colleges of Education & 5 \\
Total & 241 \\
\hline
\end{tabular}

\subsection{Research Instruments}

The research instruments used for amassing data in this study were close-ended questionnaire and interview guide. The questionnaire was used to collect data from the primary school teachers. The questionnaire was considered indispensable because it permitted the researcher to collect a large amount of data within a short time. Interview guide on the other hand was considered because it enable the researcher to gather in-depth data from the targeted art tutors of colleges of education in Ghana. Research instruments are the tools that will provide data a researcher seeks for answering research questions or testing hypotheses [15].

\subsection{Data Collection Procedure}

A self-developed closed-ended questionnaire was used to collect data from the primary school teachers. The questionnaire was categorised into section $\mathrm{A}, \mathrm{B}, \mathrm{C} \& \mathrm{E}$. Section A was about their demographic characteristics. Section B was about the grades teachers obtained in visual arts during their training in college while Section $C$ was on the availability of teaching and learning resources for quality delivering of primary school creative arts curriculum. Section D part of the questionnaire highlighted the relationship between teachers' academic achievements of the teachers in visual in college and their subject matter competency. Finally, section E portion of the questionnaire was on influence of availability of teaching and learning resources on quality delivering of primary schools creative arts curriculum. Fivefold Likert scale type of questionnaire such as Strongly Agree (SA), Agree (A), None, Disagree (D) and Strongly Disagree (SD) was employed. Before scoring, the Strongly Agree (SA) and Agree (A) categories were integrated into an Agree group, whilst the Strongly Disagree (SD) and Disagree (D) were added to form a Disagree
Category. 'None' category was maintained.

Interview guide was another instrument used to collect data from some of the primary school teachers targeted. The interview guide was also divided into $\mathrm{A}, \mathrm{B}, \mathrm{C} \& \mathrm{E}$. and the variables measured in the questionnaire were the same as the ones in the interview guide. Prior to the interview, the researcher visited the interviewee in order to:

i. ask permission to have an interview with him or her.

ii. explain the motive of the research to him/her, and

iii. seek for an appointment date and time.

The interview guide was sent to the interviewee for him/her to prepare. Permission was sought from the interviewee to record the conversation during the time of the interview with textile graduates. Interviewees were interviewed in their schools.

\subsection{Data Analysis}

Statistical Package for Social Sciences (SPSS) was used to analyse the quantitative data collected from close-ended questionnaires. Both descriptive and inferential statistics were employed in quantitative data analysis. Inferential statistic such point-biserial correlation was used to test the null hypotheses formulated at $\mathrm{p}<0.05$ alpha level of significance. The open-ended questionnaire and interview analyse manually under the various themes.

\section{Results}

$\mathrm{HO}_{1}$ : Colleges of education graduates academic achievements in visual arts have no relationship with their subject matter competency for quality delivering of primary school creative arts curriculum.

To obtain the results of $\mathrm{H}_{1}$ : which stated that colleges of education graduates academic achievements in visual arts have no relationship with their subject matter competencies for quality delivering of primary school creative arts curriculum, point-biserial correlation coefficient was used. This inferential statistical tool was employed because it is a tool normally used for testing the relationship between independent variables and dependent variables in a research. Table 2 shows the results of this analysis.

Table 2. Point-Biserial Correlation between Academic Achievements of Trained Teachers in Visual Arts and their Subject Matter Competencies for Quality Delivering of Visual Arts Component of Primary Schools Creative Arts Curriculum.

\begin{tabular}{|c|c|c|}
\hline Variable & Point-Biserial Correlation(r) & Sig. (2-tailed) \\
\hline $\begin{array}{l}\mathrm{H} 0_{1} \text { : Colleges of education graduates academic achievements in visual arts have no significantly } \\
\text { positive relationship with their subject matter competency for quality delivering of primary school } \\
\text { creative arts curriculum. }\end{array}$ & $.177^{* *}$ & 0.06 \\
\hline
\end{tabular}

\footnotetext{
**. Correlation is significant at the 0.01 level (2-tailed) $N=236$
}

Table 2 revealed that there is no relationship between academic achievements of colleges of education graduates in visual arts and their subject matter competency for quality delivering of primary school creative arts curriculum ( $\mathrm{r} p=.177^{* *}, \mathrm{n}=236, p=0.06, R 2$ $=0.06)$. The null hypothesis $\left(\mathrm{HO}_{1}\right)$ that stated colleges of education graduates academic achievements in visual arts have no relationship with their subject matter competencies for quality delivering of primary school creative arts curriculum has been accepted because the point-biserial correlation coefficient of $\mathrm{r} p b=.177^{* *}$ and the $p$-value (0.06) was above the significance level (0.05). This suggests that the grades colleges of education graduates achieved in visual arts in college never reflected their 
subject matter competency for quality delivering of primary school creative arts curriculum.

$\mathrm{HO}_{2}$ : Visual arts teaching and learning resources have no relationship with the quality delivering of primary schools creative arts curriculum.
To test the null hypothesis $\mathrm{HO}_{2}$ which stated that visual arts teaching and learning resources have no relationship with the quality delivering of primary school creative arts curriculum, inferential statistic such as point-biserial correlation coefficient was used. Table 3 shows the results of these analysis.

Table 3. Point-Biserial Correlation between Availability of Visual Arts Teaching and Learning Resources and Quality Delivering of Primary Schools Creative Arts Curriculum.

\begin{tabular}{|c|c|c|}
\hline Variable & Point-Biserial Correlation (r) & Sig. (2-tailed) \\
\hline $\begin{array}{l}\mathrm{HO}_{2} \text { : Visual arts teaching and learning resources have no significantly positive relationship } \\
\text { with the quality delivering of primary school creative arts curriculum. }\end{array}$ & $.195^{* *}$ & 0.03 \\
\hline
\end{tabular}

**. Correlation is significant at the 0.01 level (2-tailed) $N=236$

The findings in table 2 showed that there was a statistically significant positive relationship between availability of visual arts teaching and learning resources and quality delivering of primary schools creative arts curriculum ( $\mathrm{r} p b=.195^{* *}, \mathrm{n}=236$, $p=0.03, R 2=0.03)$. The null hypothesis $\left(\mathrm{H}_{2}\right)$ that stated visual arts teaching and learning resources have no relationship with the quality delivering of primary schools creative arts curriculum has been rejected because the pointbiserial correlation coefficient of $\mathrm{r} p b=.195^{* *}$ and the $p$-value (0.03) was less than the significance level (0.05). The study therefore, concluded that visual arts teaching and learning resources have positive relationship with the quality delivering of primary schools creative arts curriculum.

\section{Discussions}

Objective 1: To find out if colleges of education graduates academic achievements in visual arts reflect their subject matter competencies for quality delivering of primary schools creative arts curriculum.

In response to whether or not colleges of education graduates academic achievements in visual arts in college reflect their subject matter competency for quality delivering of the primary school creative arts curriculum, the findings from both quantitative and qualitative data indicated that the academic performance of colleges of education graduates in visual arts during their training in college do not truly reflect their subject matter competency for quality delivering of the primary school creative arts curriculum.

The findings indicated that even though majority of the graduates of colleges of education obtained quality grades ranging from A-C in visual arts during their training, most of them were not competent enough in visual arts subject matter and so find it difficult to deliver the primary school creative art curriculum effectively. It was found out that primary school teachers from colleges of education lack adequate subject matter for quality delivering of visual arts components of the primary creative arts curriculum due to insufficient contact and credit ours allotted to visual arts lessons in colleges of education in Ghana.

The study discovered from the interview conducted with lecturers that visual arts is studied as a core subject in one semester to equip trainees with content knowledge they needed to deliver the primary schools creative arts curriculum. The few trainees who selected visual arts as an elective subject in second year studied principles and methods of teaching visual arts in second year first semester. During second semester of second year, there were five visual arts options (visual communication, fabric \& leather decoration, weaving \& stitching, assemblage \& construction, and casting, modelling \& carving) in which a trainee teacher selected only one option as his or her elective subject based on the college visual arts lecturers' area of specialisation. Meanwhile in primary schools, a graduate of colleges of education were to teach all the five visual arts subject areas mentioned above.

Also, it was revealed that only 2 hours allotted to compulsory visual arts lessons per week and 1 hour per week for second year elective visual arts subjects because the visual arts subjects were 1 credit hour subjects. These inadequate contact hours were supposed to be used for teaching and learning of skills the trainees needed to effectively deliver the creative arts curriculum after their training in college. The study also discovered that graduates of colleges of education who completed their training four and above years ago studied a different visual arts curriculum in college and so lack adequate skills to deliver the contents of the current primary schools creative arts curriculum which matches the current colleges of education visual arts curriculum.

Objective 2: To assess the teaching and learning resources available for quality delivering of visual arts component of primary schools creative arts curriculum.

The study discovered that creative arts textbooks were not available in most of the primary schools. The creative art textbooks in the few primary schools having them were not enough for the pupils. For example, in some primary schools only one creative arts textbook was available for a class of 19 and above pupils. It was also revealed that apart from creative arts textbooks, modern teaching and learning resources such as televisions, DVD players and CDs that can support effective teaching and learning of visual arts were also not available in the primary schools. Also, it was revealed that visual arts teaching and learning materials such as drawing papers, crayon, dyes, calico, dyeing chemicals etc. and practical tools were not available for effective delivering of the visual arts component of the creative arts curriculum.

The findings on non-availability of teaching and learning resources indicated that Ghana primary schools were operating with insufficient or without visual arts teaching and 
learning resources, tools and materials which compromises rationales for the creative arts curriculum in Ghana primary schools. These findings are in support of the researcher (16) who states that non availability of teaching and learning resources hindered learners learning of new knowledge and skills in vocational courses. The findings also agrees with the study [17] who indicated that lack of resources could also lead to cuts in the volume of practical training expected to be provided to learners in the classroom.

\section{Conclusion}

The main purpose of this study was to investigate colleges of education graduates academic achievements in visual arts and their subject matter competency for quality delivering of visual arts component of the primary schools creative arts curriculum. The findings of $\mathrm{HO}_{1}$ indicated that colleges of education graduates academic achievements in visual arts have no relationship with their subject matter competencies for quality delivering of primary schools creative arts curriculum. $\mathrm{HO}_{2}$ discovered that visual arts teaching and learning resources have a positive relationship with the quality delivering of primary schools creative arts curriculum.

Based on the findings of this study, it was concluded that the colleges of education graduates academic achievements in visual arts during their training do not reflect the subject matter skills they possess for quality delivering of visual arts components of the primary schools creative arts curriculum. The study also concluded that primary schools lack teaching and learning resources for quality delivering of visual arts component of primary schools creative arts curriculum.

\section{Recommendations}

i. Ghana Education Service should liaise with visual arts units of vocational education department in colleges of education to periodically organise workshops and seminars for primary school teachers to enhance their subject matter competency.

ii. Contact hours for teaching and learning of visual arts subjects in colleges of education should be at least 3 hours per week to enable lecturers equip trainee teachers with adequate skills for quality delivering of the primary school creative arts curriculum.

iii. Ministry of Education through Ghana Education Service should supply creative arts textbooks, modern visual arts teaching and learning resources and tools and materials lacking in primary schools to promote effective teaching and learning of creative arts.

\section{References}

[1] Institute of Education, University of Cape Coast, (2014). Visual arts course outline for colleges of education. Cape Coast, Ghana: Institute of Education, University of Cape Coast.

[2] Eze, T. I., Ezenwafor, J. I. \& Obi, M. N. (2015). Effects of age and gender on academic achievement of vocational and technical education (VTE) students of a Nigerian university. Journal of Emerging Trends in Educational Research and Policy Studies, 6 (1), 96-101.

[3] Ali, S. (2013). Factors affecting academic achievement of students. American Journal of Educational Research 1 (8), 283-289.

[4] Ng'ang'a, M. Mwaura, A. M. \& Dinga, J. N. (2018). Relationship between achievement goal orientation and academic achievement among form three students in Kiambu County, Kenya. International Journal of Education and Research, 6 (4), 53-68.

[5] Rabgay, T. (2015). A study of factors influencing students' academic performance in a Higher secondary school in Bhutan. Educational Journal CERD, 16 (2), 73-97.

[6] Jayanthi, S. V., Balakrishnan, S. Ching, A. L. S., Latiff, N. A. A. \& Nasirudeen, A. M. A. (2014). Factors contributing to academic performance of students in a tertiary institution in Singapore. American Journal of Educational Research, 2 (9), 752-758.

[7] Ouma, N. O. \& Munyua, J. K. (2018). Relationship between teachers' working conditions and students' academic performance in public day secondary schools in Nyando subcounty, Kenya. British Journal of Education, 6 (5), 52-58.

[8] Zheng, M. (2015). Conceptualization of cross-sectional mixed methods studies in health science: A Methodological review. International Journal of Quantitative and Qualitative Research Methods, 3 (2), 66-87.

[9] Banerjee, A. \& Chaudhury, S. (2010). Statistics without tears: Populations and samples. Industrial Psychiatry Journal, 19 (1), 60-65.

[10] Etikan, I. Musa, S. A. \& Alkassim, R. S. (2015). Comparison of convenience sampling and purposive sampling. American Journal of Theoretical and Applied Statistics, 5 (1), 1-4.

[11] Creswell, J. W. (2014). Research design: Qualitative, quantitative and mixed methods approaches (4th ed.). Thousand Oaks, CA: Sage.

[12] Naderifar, M., Goli, H. \& Ghaljaie, F. (2017). Snowball Sampling: A purposeful method of sampling in qualitative research. Strides in Development of Medical Education, 14 (3), 1-2.

[13] Kombo, D. K. and Tromp, L. A. (2006). Proposal and thesis writing: An introduction. Nairobi: Pauline's Publication of Africa.

[14] Taherdoost, H. (2016). How to design and create an effective survey/questionnaire: A step by step guide. International Journal of Advance Research in Management, 5 (4), 37-41.

[15] Tazikeh, E. (2015). Research methodology: Tools and techniques. Romania: BRIDGE CENTER.

[16] Right, J. (2018). The importance of learning materials in teaching. United State of America: Leaf Group Ltd. / Leaf Group Education.

[17] Kigwilu, P. C. (2014). Determinants of effective implementation of artisan and craft curriculum in catholic sponsored community colleges in Nairobi region, Kenya $(\mathrm{PhD}$ thesis). Faculty of Education, Catholic University of Eastern Africa Nairobi, Kenya. 